\title{
RESUMOS DOS TRABALHOS APRESENTADOS NAS REUNIOES CIENTIFICAS DO DEPARTAMENTO DE HIGIENE E MEDICINA TROPICAL DA ASSOCIAÇÃO PAULISTA DE MEDICINA, EM SETEMBRO DE 1971
}

Reunião científica de 17-9-1971

CORRÊA, R. de R. \& RosárIo, F. F. - Técnica de Kato e Miura: estudo de alguns aspectos básicos.

Resumo: Conciliando simplicidade de execução com a eficiencia dos processos de enriquecimento, a técnica de Kato e Miura desperta particular interesse, em nosso meio, sob o ponto de vista do diag. nóstico da esquistossomíase mansoni por meio do exame das fezes. Utilizando-se 200 amostras de fezes humanas normais, estudaram-se aspectos unitários do processo com o fim de.determinar, não só suas teses teóricas, mas também sua adaptabilidade a diversas situações práticas. Prensagem das fezes: sem acréscimo de líquido, as fezes prensadas de modo a formar preparações de $0,1 \mathrm{~mm}$ mostram-se mais diáfanas do que esfregaços, da mesma espessura, diluídos em água. Laminula flexivel: adaptando-se às irregularidades da superfície do esfregaço, permite $o$ afastamento de detritos entre os elementos parasitários e a superfície interna da mesma. Solução de glicerina: por causa de seu alto índice de refração ( $\mathrm{n}=1,411)$ atua como diafanizadora. Po- de ser substituída por outros líquidos, miscíveis em água, empregados na montagem de preparações microscópicas (goma de Apáthy, geléia de glicerina, soluções de sacarose, etc.). Não sendo possível a verificação da viabilidade dos ovos de Schistosoma mansoni em preparaçōes feitas segundo a técnica original de Kato e Miura, por causa da ação da solução de glicerina, observa-se que a simples prensagem de uma porção de fezes, sem acréscimo de qualquer líquido, permite, não só o diagnóstico, mas também a visualização dos miracídios. Nesse caso, mostraram-se mais adequadas lamínulas de plástico impermeável. O rendimento é apenas um pouco menor do que o que se consegue com acréscimo de líquido diafanizador. Geléia de glicerina, acrescentada em pequenas quantidades diafanizadoras resultantes de seu alto índice de refração $(n=1,474)$ com a preserva. ção dos miracídios.

Unitermos: Técnica de Kato e Miura*; Enteroparasitoses*; Schis tosoma mansoni*. 
Ramos, A. da S.; Piza, J. de T.; Morais, L. V. C. de \& TAкATU, L. - Biomphalaria glabrata (Pulmonata - Planorbidae) no Estado de São Paulo, Brasil.

Resumo: O propósito de melhor conhecer a disseminação da Biomphalaria glabrata no Estado de São Paulo levou a Superintendencia da Campanha de Combate à Esquistossomose a intensificar os trabalhos de investigação, cujos resultados são agora apresentados. A pesquisa foi realizada em 355 municípios dos 572 do Estado. Até o presente, Biomphalaria glabrata havia sido assinalada em $6 \mathrm{mu}$ nicípios do Estado de São Paulo. Com os resultados ora obtidos elevou-se para catorze o número de municípios onde ela ocorre, todos localizados no Vale do rio Paranapanema. Incluindo os municípios anteriormente registrados, a existencia de biótipos naturais de glabrata foi verificada nos seguintes: Assis, Candido Mota, Chavantes, Coronel Macedo, Far- tura, Ipauçu, Itapeva, Itaporanga, Ourinhos, Ribeirão do Sul, Santa Cruz do Rio Pardo, Taquarituba, Taguaí e Itaberá. Os criadouros observados foram, na ordem de maior frequiencia, os seguintes: córregos, nascentes, valas de drenagens, valas de irrigação, lagoas, depressões naturais, canteiros de agriăo, tanques, escavações de olaria (antigos barreiros), escavaçōes de pedras e brejos. Em alguns desses criadouros tem sido observada a coexistencia de B. glabrata com B. peregrina ou com $B$. intermedia. Com referencia a focos ativos, foram verificados indices de infecção natural em Assis (1,4 a $5,3 \%)$, Ipauçu $(0,49 \%)$ e Ourinhos 0,08 a 5,3\%). Um quadro e um mapa do Estado com municípios onde este planorbídeo foi encontrado são também apresentados.

Unitermos: Biomphalia glabrata"; Planorbidae*; Esquistossomose*; Biomphalaria peregrina; Biomphalaria intermedia. 